\title{
Pampas Deer Project
}

\author{
John Jackson
}

Commercial hunting, habitat destruction, poaching, competition with domestic livestock and infection by their diseases, especially foot-and-mouth, have all contributed to reduce the once extremely abundant venado to an estimated wild population today of about 80 animals. The author with other Argentinian scientists is making a study, financed by WWF, in preparation for management plans that it is hoped will save this endangered deer.

The venado Ozotoceros bezoarticus celer, the southernmost of the three subspecies of the South American pampas deer, was once extremely abundant in the Pampas of central Argentina, as the reports of explorers and pioneer settlers clearly show; its range extended across the whole of this vast natural grassland region, and as late as 1900 , it still occurred throughout the region. ${ }^{2}$ Yet today this race has become the most highly endangered cervid in South America. ${ }^{4}$ In less than a century a catastrophic population crash has brought them to the verge of extinction. The wild population is today estimated at 80 animals in three or four widely separated locations and marginal habitats and even the survival of these herds is threatened. There is also a group of 20 animals in a specially built enclosure on the estancia La Corona, ${ }^{1}$ which were captured in the late 1960s on the coast of the Bay of Samborombon, ${ }^{5}$ thus further reducing the already dwindling wild populations. No other venado are known elsewhere.

Commercial trade in skins was one of the big factors in reducing these deer. By the late 19 th century, they were being hunted commercially on a large scale, and many thousands of skins exported annually. For example, Daguerre $^{3}$ calculated that the trade in $1860-70$ amounted to $2,130,000$ skins, and according to the Estadistica de Caza (Hunting Statistics) 61,401 pelts were exported in 1880 from Buenos Aires alone, figures which, even if not totally reliable, indicate the magnitude of the slaughter.

The venado were also killed for a variety of other reasons. The skin was reputed to be a charm to ward off venomous snakes, so many gauchos wore a thong of it or incorporated hide into their horses' tack; medicinal properties were attributed to the unusual stomach stones found in the animal; and hunting for the pot and for sport, using both firearms and the traditional boleadoras, reduced the herds still further. Poaching is still a major threat today.

\section{Habitat Going}

During the past few centuries the original pampas habitat in which the venado thrived has disappeared. With increasing human occupation the pampas have been drained and the land 'improved' to create the vast uniform expanses of livestock-rearing pastures which typify the Argentinian pampas today. Introduced domestic and exotic animals probably competed with the venado for the available food and living space in this new environment, and some of the livestock diseases, particularly foot-and-mouth, were transmitted and may have decimated the deer populations. 
The cumulative effects of these adverse factors have resulted in the venado's present plight. To avert its inevitable disappearance, thorough ecological studies are being made to try to establish a sound basis for the proper conservation and management of both the deer and their remaining habitats before it is too late. A multidisciplinary team of Argentinian scientists from the University of La Plata is working with the official bodies and other interested parties in a co-ordinated and concerted effort to save the venado. WWF has provided support (Project 1303) to augment local resources, and has also sponsored the author to work with the Argentinian scientists. The project is the first of its kind in the Republic of Argentina and hopefully will promote and stimulate similar action for the country's other endangered wildlife, such as the jaguar, pudu and giant armadillo.

\section{References}

1. BIANCHINI, J. J. \& PEREZ, C. L. N. 1972. El comportamiento de Ozotoceros bezoarticus celer Cabrera en cautiverio. Acta Zoológica Lilloana 29, 5-16.

2. CABRERA, A. 1943. Sobre la sistematica del venado y su variación individual y geográfica. Revista del Museo de La Plata Tomo 3, Sección Zoológia, 5-41.

3. DAGUERRE, J. B. 1970. El venado o ciervo de la Pampas. Diana 363, 20-24.

4. HOLLOWAY, C. 1975. Threatened deer of the World: Research and conservation projects under the IUCN programme. Deer $38,428-433$.

5. WHITEHEAD, G. K. \& ANCHORENA, M. de 1972. Operation Pampas Deer. Country Life 7.9.72, 596.

Author; El Museo, Paseo del Bosque, La Plata, Republica Argentina.

\section{The Mess That Jack Built}

'Ecological disaster concealed in a shipment of nursery plants struck Bermuda about 1946. In just three years nearly half the Bermuda cedars were dead or dying. By 1951,85 per cent had been wiped out. The culprit, a scale insect, was a notorious pest of ornamental and citrus plants.' This is quoted from an article by Kenneth L. and Marnie Reed Crowell in the October 1976 Natural History. The authors describe how government officials tried to control the scale insect by introducing predators. First, ladybird beetles and parasitic Hymenoptera were brought in, but these were eaten by small Angius lizards (which had also been previously introduced as predators) and by two introduced species of ants. It was then decided to control the lizards (even though they were eating the ants) by introducing the kiskadee, a large West Indian flycatcher, and in 1956/57, despite protests from local conservationists, some 200 were released in the hope that they would eat the lizards that ate the ladybirds that ought to eat the scale insects that killed the cedars. Now the kiskadee has increased to an estimated 60,000 , preys on the nestlings of the native Bermuda white-eyed vireo, and has contributed its share to the great decrease that has occurred in the native bird populations.

\section{Is Przewalski's Horse Changing?}

The shape of the legs and head of Przewalski's horse may be changing because of the negative selection inherent in its long captivity, and also the fact that all 254 animals held today are descended from the same 54 individuals brought to Europe between 1899 and 1904. In a report published by the Prague Zoo, Jiri Volf pleads for the establishment of a well-guarded Przewalski's-horse reserve in the wild. The ground would need to be hard and sandy to prevent ingrowing of the horn on the hooves, the climate arid, and the grass tough enough to develop chewing muscles; protection against domestic horses would be essential. 